\title{
Belphégor
}

Littérature populaire et culture médiatique

\section{Mark Bould and Williams Rhys, Sf Now}

\author{
Amy J. Ransom
}

\section{(2) OpenEdition}

\section{Journals}

Electronic version

URL: http://journals.openedition.org/belphegor/571

DOI: 10.4000/belphegor.571

ISSN: 1499-7185

\section{Publisher}

LPCM

\section{Electronic reference}

Amy J. Ransom, « Mark Bould and Williams Rhys, Sf Now », Belphégor [Online], 13-1 | 2015, Online since 09 May 2015, connection on 22 September 2020. URL : http://journals.openedition.org/ belphegor/571 ; DOI : https://doi.org/10.4000/belphegor.571

This text was automatically generated on 22 September 2020.

\section{(c)}

Belphégor est mis à disposition selon les termes de la Licence Creative Commons Attribution - Pas d'Utilisation Commerciale - Pas de Modification 4.0 International. 


\title{
Mark Bould and Williams Rhys, $S f$
} Now

\author{
Amy J. Ransom
}

\section{REFERENCES}

Bould, Mark, and Rhys Williams. Sf Now. Paradoxa 26, 2014. ISBN 978-1-929512-37-9.

Paperback. 316 pp. $\$ 24.00$ (individuals) $/ \$ 48.00$ (institutions) 
1 Who said the Left is dead? It is alive and kicking in a major strain of science-fiction writing and criticism as witnessed in the most recent edition of the annual journal Paradoxa, edited by Mark Bould and Rhys Williams appropriately titled $s f$ Now. If this is a publication that is not on your radar because of its annual appearance, if you are interested in rigorous, cutting edge scholarship, you should check it out (paradoxa.com). With an international editorial board that includes such heavy hitting academics as Brian Attebery, Takayuki Tatsumi, Mark Bould, and Vivian Sobchack, as well as writers of the caliber of Michael Moorcock, Ursula K. LeGuin and Élisabeth Vonarburg, its quality is assured and this issue is no exception. If you read only one book or journal about science fiction this year,

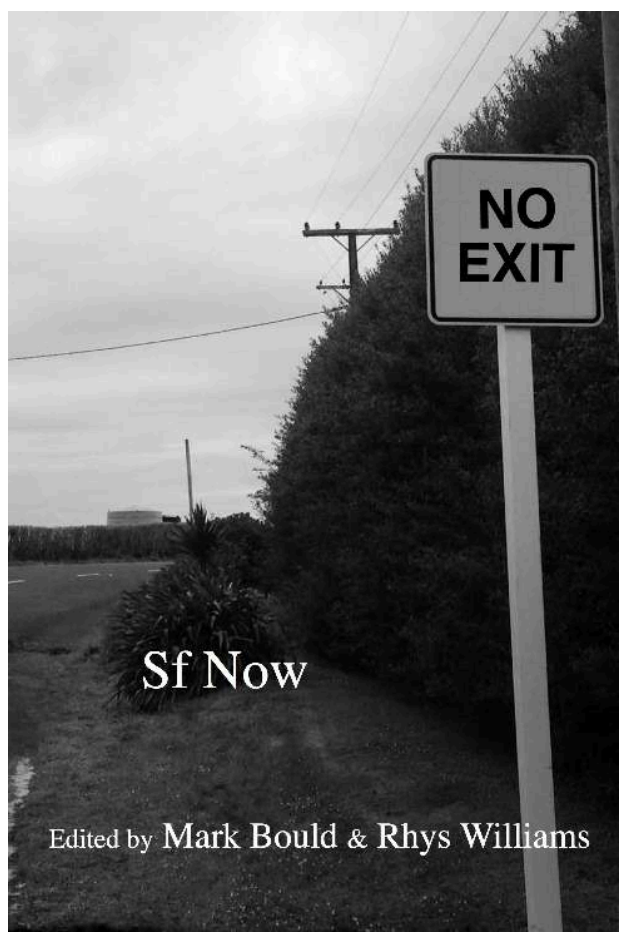
choose this special issue for coverage of the state of the art in sf criticism and theory. If sf if your field of speciality, this is a must read.

2 Sf Now includes two book reviews, five interviews, and fourteen critical essays most of which explore three major themes: the possibility of science-fictional critiques of neoliberalism and our capacity to imagine the post-capitalist world; the framework of energy studies as applied to sf and other texts; the post- and trans-human, particularly in relation to animal studies. All of these essays are themselves on the cutting edge of the field either for their choice of primary corpus, their theoretical approach, or both. The issue's contributors include established names in sf criticism, including Carl Freedman, Sherryl Vint, and Veronica Hollinger, as well as rising stars like Gerry Canavan and Rhys Williams. These critics share with the authors they explicate an overarching concern about the impact of neoliberal economics on world cultures, economies and environments, approaching sf as a genre ripe with critical potential in a global conjuncture in which a major change in paradigm has become increasingly necessary. The authors selected for interview by the journal reveal largely a very similar outlook and signify the changing face of sf and the coming-of-age of what has been referred to as postcolonial sf: Kij Johnson interviewed by Joan Gordon; Junot Díaz interviewed by Taryne Jade Taylor; Stephen Graham Jones (Piegan Blackfeet) interviewed by Grace Dillon (Anishinaabe); and Nnedi Okorafor interviewed by Jessica Langer. In addition, Rhys Williams interviews academic and author of Humanity 2.0: What it Means to be Human Past, Present and Future (2011).

In a stand-alone piece, Andrew Milner proposes a new model for our understanding of sf as a world cultural phenomenon, drawing on Franco Moretti's application of Emmanuel Wallerstein's “world systems" model to comparative literature. Milner proposes a similar system in which sf developed out of an Anglo-French centre in the nineteenth-century, coupled with various semi-peripheral national sf's which fed its 
creative development. Of course, the US nudged itself into centre-position by the second half of the twentieth century, with Japan becoming an increasingly important contributor to the genre. Milner's model offers a new way to examine national sfs, a sub-field of sf criticism that continues to grow as new and often unexpected cultural groups appropriate the tropes of sf to tell their own stories. Also somewhat on the side lines of the issue's main thrust, two essays approach the genre of alternate history: Glyn Morgan rehearses the truism that alternate histories are really stories about now, while Mark Jerng goes a bit farther in "The Use and Abuse of Racial Counterfactuals: Reimagining Emancipations in Alternate History and US Antidiscrimination Jurisprudence." He analyses how a number of familiar AH works use the estrangement of race reversal simply to reinscribe dominant values, whereas others really do work to destabilize the category of race, ending on an interesting discussion of how a racial counterfacutal was used in the deliberations of the Supreme Court case of Ricci v Stefano (2009).

4 Three essays address the notion of "capitalist realism" and the dictum that in the current neoliberal cultural and economic climate it has become impossible to represent life after capitalism, arguing against such pessimism and proposing that, indeed, a number of sf writers and filmmakers continue to attempt to do so. In "Capitalist Realism in Three Recent Sf Films," however, Carl Freedman demonstrates how Gravity (2013, dir. Alfonso Cuarón) and Her (2013, dir. Spike Jonze) fail at this task whereas Steven Soderberg's Side Effects (2013) partially succeeds. Gerry Canavan also looks at recent film, observing how Bong Joon-ho's Snowpiercer (2013) and the French graphic novel it was based on, attempt to break with a dominant aesthetic of "necrofuturism," which can only imagine the future result of neoliberal capitalism as a cemetery wasteland. Zak Bronson examines China Miéville's novel Railsea (2012) as also seeking to go beyond the apocalypse in its depiction of a culture of recyclage and repurposing. The leftist critique continues in two essays focusing more particularly on energy's role in both sf and reality. Graeme MacDonald's "Improbability Drives: The Energy of Sf" engages with the "energy humanities" which consider energy sources as being culturally implicated as much as they are bound by technology and the environment. $\mathrm{He}$ argues that sf is, of course, the privileged literary genre for such investigations given the central role of energy in so many sf plots and tropes. Applying his notion to three specific sub-genres (space opera, post-apocalyptic narratives, and the lost world), he draws examples across the history of sf from George Lucas's original Star Wars (1976) film to the novels of M. John Harrison, and Cormac McCarthy's The Road. Brent Bellamy offers an interesting reading of Michael Madsen's 2010 documentary about the Finnish nuclear waste disposal project through a similar lens in "Into Eternity: On Our Waste Containments and Energy Futures."

5 Exploring the possibilities of the transhuman, and disentangling it from the confusingly similar term of the posthuman represents a significant task for science fiction writers and critics today, particularly given the political implications of each category. Transhumanism, the concept proposed by Ray Kurzweil merely extends the current neoliberal model which accepts that some individuals are more human than others. In contrast, the posthuman, or what Pramod K. Nayar specifies as "critical posthumanism" (Nayar, Posthumanism, Polity, 2014) imagines humanity itself as a fluid category always already engaged relationally with the machines, animals, and other organisms around us. Sherry Vint applies the latter conceptualization in her concern for integrating animal studies into sf, looking in particular at Karen Joy Fowler's We Are 
All Now Completely Beside Ourselves (2013) and its plot in which a couple raises a great ape as a sister to their own daughter, at once untangling and complexifying the implications that such an experiment has in relation to the "humanity" of all of those involved. Human animal experiments recur in the primary text that Rhys Williams selects to test his developing theoretical contribution that will both salvage and transcend Darko Suvin's notion of "cognitive estrangement" in "Cognitive Impurities: A Combined Political Approach to the Fantastic (with The Island of Doctor Moreau). (Williams further develops this approach in a contribution to Science Fiction Studies 41.3 [November 2014], "Recognizing Cognition: On Suvin, Miéville, and the Utopian Impulse of the Contemporary Fantastic.") Tom Tyler examines the videogame Plague, Inc. identifying its premise of the player selecting a pathogen and playing out a scenario until she has eradicated all of humanity as a new form of "Misanthropy without Humanity," as his essay is titled. Veronica Hollinger riffs on the title of Steve Fuller's book in "Humanity 2.0: Retrospection, Abjection, and the Future-to-Come" which explores the usefulness of Mark Currie's notion of "retrospective anticipation" in works by Greg Egan, Paolo Bacigalupi, and Kim Stanley Robinson. Describing the latter as "the most significant writer of utopian fiction working today" (277), Hollinger concludes that he offers the most hopeful vision of humanity's possible future evolution in 2312 (2012). Finally, Dan Hassler-Forest closes the volume with "The Politics of WorldBuilding" and the presence of Bakhtin's heteroglossia in visual artist Janelle Monáe's "Afrofuturist WondaLand."

Having read a good portion of the entire body of sf criticism produced in 2014 while serving as a juror on the Science Fiction Research Association's Pioneer Award committee, I can back up my claims as to the importance of this volume. Having been a regular book reviewer for such journals as Science Fiction Studies, Journal of the Fantastic of the Arts, and Extrapolation I have read a lot of mediocre edited volumes over the last six or seven years. This journal issue is, along with Blast, Corrupt, Dismantle, Erase: Contemporary North American Dystopian Literature (Wilfrid Laurier UP, 2014) edited by Brett Josef Grubisic, Gisèle M. Baxter, and Tara Lee, the best collective work of sf scholarship I've read for a number of years. Paradoxa 26 lives up to its name giving its readers a rigorous account of what is $S f$ Now. 